\title{
Triune Ethics Theory and Moral Personality ${ }^{1}$
}

\author{
DARCIA NARVAEZ
}

\section{言}

Triune Ethics Theory (TET; Narvaez, 2008) is a meta-theory that draws together the findings of multiple research programs to propose three foundational ethical motivations. The three ethics - Security, Engagement, and Imagination - formed from evolved strata of the brain, are manifest in the moral lives of individuals and groups. The higher levels of moral functioning, Engagement and Imagination, depend on early nurturing for their optimal development. In this chapter, I describe the theory and its relation to moral personality, including how dispositions can be formed around one of the ethics, and situations can influence which ethic is activated.

\section{Grounding Three Ethics}

Triune Ethics Theory (TET) identifies three types of orientations that underlie human morality and that emerged from biological propensities in human evolution. Deriving its name and inspiration from MacLean's (1990) Triune Brain theory, Triune Ethics Theory identifies moral orientations that reflect in some sense MacLean's three evolutionary strata that resulted from "relatively long periods of stability in vertebrate brain evolution" (Panksepp, 1998, p. 43). Each stratum retains an identifiable mark on the brain and human behavior. TET notes their engineering of moral behavior in terms of cognitive and emotional propensities.

Emotion underlies basic functions in the brain. Emotional systems guide the animal in forming adaptive solutions to environmental demands. These systems involve "psychobehavioral potentials that are genetically ingrained in brain development" as "evolutionary operants" (Panksepp, 1998, p. 55). Centrally situated to interact dynamically with higher-order cognitive structures and lower-level physiological and motor outputs,

\footnotetext{
${ }^{1}$ Preparation of this chapter was facilitated by a grant from the Spencer Foundation.
} 
"emotive circuits change sensory, perceptual, and cognitive processing, and initiate a host of physiological changes that are naturally synchronized with the aroused behavioral tendencies characteristic of emotional experience" (Panksepp, 1998, p. 49). Emotional states affect "what is perceived and how it is processed, and the interpretations made of ongoing events subsequently influence emotional reactions and perceptual biases. Affect and cognition are appropriately conceptualized as interwoven processes" that guide memory formation and retrieval and perceptual vigilance, constraining the amount of attention available for reflective appraisal and response choice (Bugental and Goodnow, 1998, p. 416).

Many of the emotional component systems in the brain become integrated in early life as a function of bottom-up learning - "states constructed during early social development from more elemental units of visceral-autonomic experiences that accompany certain behavior patterns" (Panksepp, 1998, pp. 44-45). The brain's emotional command systems allow animals to adapt to life's challenges. An individual's unique brain pattern of emotional circuitry results from interaction with caregivers and other environmental supports. Recent animal and human research documents the importance of early experience on gene expression for emotional circuitry (Weaver, Szyf, \& Meaney, 2002), personality formation (Schore, 2003a; 2003b), and cognition (Greenspan \& Shanker, 2004). Environmental supports, particularly caregiver interaction with the offspring, influences whether genes are turned on or not, whether emotion regulation begins on a healthy path, and whether or not cognitive development is shaped for maximal growth.

Triune Ethics theory postulates that the emotional circuitry established early in life underpins the brain's architecture for morality and ethical behavior, influencing moral personality and potential for moral functioning. The three ethics can be described as "central motives" in the eventfeature-emotion complexes that drive moral cognitive phenomena. As motivated cognition, when a particular ethic is active, it is presumed to influence perception, information processing, goal setting, and affordances (Moll, de Oliveira-Souza, Eslinger, Bramati, Mourao-Miranda, Andreiulo et al., 2002; Moll, Zahn, de Oliveira-Souza, Drueger, \& Grafman, 2005). An activated ethic influences goal making, thereby shaping interpretation of normative claims. When an individual treats a particular orientation as a normative imperative that trumps other values, the orientation carries ethical significance. For example, the Ethic of Security is focused on selfpreservation through safety and such things as personal or ingroup dominance. When the Security Ethic is highly active, the individual will have 
a difficult time focusing on the needs of others, because this ethic resides in brain and body systems that are self-focused. Actions that prioritize self and ingroup safety over the welfare of other lives will be deemed moral. The Ethic of Engagement is oriented to face-to-face emotional affiliation with others, particularly through caring relationships and social bonds; when it is active, the individual will be focused on the needs of others; compassionate action will seem most moral. Physiologically, the Security Ethic and the Engagement Ethic are based in incompatible systems. The former is related to increased stress hormones (norepinephrine/adrenaline) that tie up organism energy for fight or flight, while the latter is related to calming hormones (e.g., oxytocin) that fuel trust of others. When energized by the emotional systems of the brain, the Imagination Ethic can be linked to either Security (reptilian cleverness) or Engagement (compassion with wisdom). The Ethic of Imagination uses humanity's fullest reasoning capacities to adapt to ongoing social relationships and to address concerns beyond the immediate; it allows the individual to step back from and review instincts and intuitions.

Some basic preliminary information follows regarding underlying assumptions about how moral personality may be influenced by the three motivational systems. See Table 6.1 for a comparative sampling of characteristics across ethics.

\section{TET and Personality}

Moral personality finds its beginning with gestation, birth, and early life. Fetuses and babies change growth patterns in different organs and systems based on maternal and environmental stress signals during sensitive developmental periods (Gluckman \& Hanson, 2004; Henry \& Wang, 1999). Early patterns establish orientations leading to dispositional habits and situational sensitivities for the expression of personality throughout life (Hrdy, 1999). Triune Ethics Theory proposes that these factors also impinge on moral personality.

The Importance of the Environment of Evolutionary Adaptedness (EEA) Biology matters for moral functioning as individuals and as evolved mammals (see Narvaez \& Vaydich, 2008). Human brain and body systems adapted to particular conditions of the Pleistocene era based on environmental supports; those conditions have been termed the "environment of evolutionary adaptedness" (EEA; Bowlby, 1988). Hewlett \& Lamb (2005) describe the EEA - the type of early-life supports our biological systems 


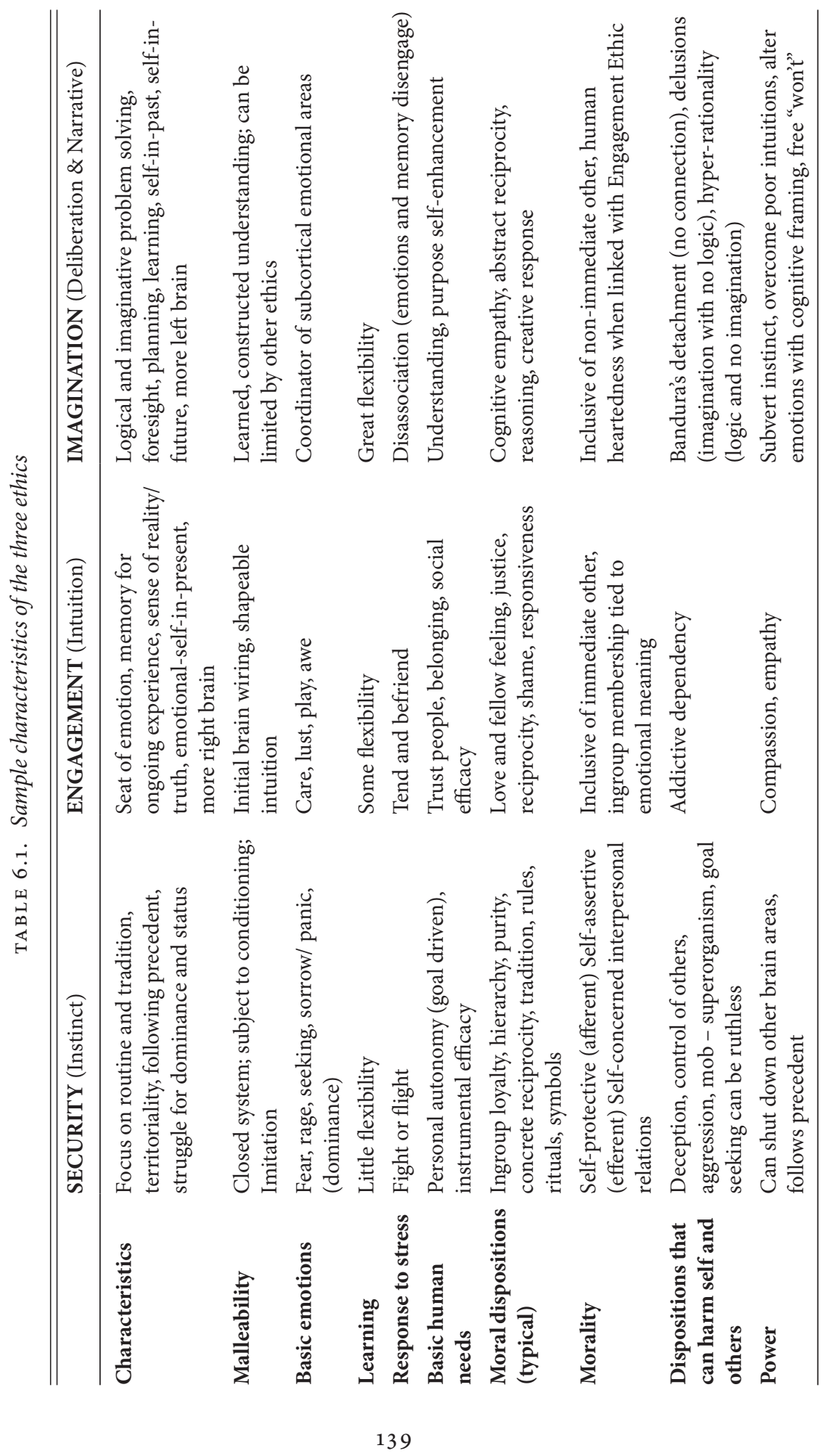


expect - summarizing the type of childcare in hunter-gatherer communities noted across anthropological studies (foraging community life is presumed to closely resemble human living during the Pleistocene). Not only does breastfeeding take place for 3-5 years, but:

young children in foraging cultures are nursed frequently; held, touched, or kept near others almost constantly; frequently cared for by individuals other than their mothers (fathers and grandmothers, in particular) though seldom by older siblings; experience prompt responses to their fusses and cries; and enjoy multiage play groups in early childhood. (p. 15)

Adapted to particular conditions of the past, human brain and body systems are not adapted to the recent social practices of hospital births, infant formula, solo sleeping, or physical isolation. Does it make any difference? Aren't humans adaptive and resilient? Yes, and yes, within limits. Evidence is accumulating about the negative effects of the missing EEA. To take one of these features, touch, we know from animal studies that a dearth of touch in the early years is related to an underdevelopment of serotonin receptors (Kalin, 1999). Caregiving in the United States typically isolates infants from close human contact for long periods of time, and offers limited responsiveness and breastfeeding (Centers for Disease Control, 2004; see Narvaez, 2008, for more detail). It is likely that these practices influence serotonin receptor development. In fact, infants with faulty serotonin receptors are more likely to die of Sudden Infant Death Syndrome (Audero, Coppi, Mlinar, Rossetti, Caprioli, Al Banchaabouchi, Corradetti, \& Gross, 2008; Paterson, Trachtenberg, Thompson, Belliveau, Beggs, Darnall, Chadwick, Krous, \& Kinney, 2006). We also know that adults with faulty serotonin receptors are more likely to become depressed (Caspi, Sugden, Moffitt, Taylor, Craig, Harrington, McClay, Mill, Martin, Braithwaite, \& Poulton, 2003) or anxious (Lesch, Bengel, Heils, Sabol, Greenberg, Petri, Clemens, Müller, Hamer, \& Murphy, 1996), states that influence general as well as moral functioning. The United States has epidemics of anxiety and depression in real numbers (USDHHS, 1999). Because of the dearth of touch, Prescott (1996) came to the conclusion that most children in the US are susceptible to Somatosensory Affectional Deprivation (SAD), a condition related to depression, violent behavior, and stimulus seeking. Effects of childrearing on moral functioning are discussed further below and elsewhere (Narvaez, 2008; Narvaez \& Vaydich, 2008).

Anthropological studies demonstrate that moral functioning is influenced by childrearing practices. Societies that stay in physical contact with 
their infants and children in the manner of the EEA are more likely to be peaceful societies (Prescott, 1996). Such experiences led to a cohesive social group that lived mostly in peaceful cooperation (Dentan, 1968). One could postulate that the range of personality differences are much greater in "civilized" nations (towards the pathological and antisocial), as a result of modern childrearing practices, than they would be under the EEA (which would give psychologists much less to do).

\section{Dispositional Effects}

TET generates two hypotheses regarding moral personality. First, taking a dispositional view, a personality may cohere around being more or less oriented to each of the three ethics. A similar idea was proposed by Tomkins (Demos, 1995) who suggested that early socialization sets up life orientations ("ideo-affective postures") that the individual subsequently applies to many domains throughout life. The ideo-affective posture developed from early experience represents a socialized "set of loosely organized feelings and ideas about feelings" (Tomkins, 1965, p. 74) that resonate with particular organized ideologies, drawing individuals to particular viewpoints: a warm, supportive childhood leads a person to orient to an open, accepting posture ("humanistic") whereas a harsh, restrictive childhood leads to a defended, rejecting posture ("normative") toward people and toward life experiences in general. Similarly, TET proposes that during critical periods of brain and personality development (e.g., neonatal), "attachment" (Bowlby) and "trust" (Erikson) aspects of personality development are deeply influenced, affecting the structure and wiring of brain systems. The development of these systems is reflected in capabilities for moral functioning and is related to personality functions. For example, stressed early experience can lead to an enhanced orientation to self, and a depressed empathic response to others (Henry \& Wang, 1998). (See Table 6.2 for possible developmental trends.) Situations can also influence which ethic is activated.

\section{Situational Effects}

Second, according to a social-cognitive view of moral personality (Mischel, 1973; Cervone, 1999), moral personality has a dispositional signature within particular situations: person and situation interact with dispositional regularity. TET suggests that individuals are morally driven, desiring the good as it is perceived in the moment. Thus, one's moral perspective may shift from one ethic to another, depending on the press of the situation and what that situation evokes in the moment. The individual may also experience the activation of conflicting ethics - shifting between Security (self-concern) 
TABLE 6.2. Possible crystallized ethical personality types ${ }^{123}$

Initial Propensities Enhanced or Diminished by Caregivers

Drives for ATTACHMENT, SEEKING, PLAY, WONDER

Developmental Trajectory in Stress

Conditions

Emotions/Drives emphasized: FEAR, ANGER,

PANIC/SORROW, outward SEEKING

Emotions/Drives suppressed: LOVE (LUST/

CARE /ATTACHMENT), PLAY, inward SEEKING

\section{Solo Security}

Orientation to feeling safe either with a constant defensive manner and through seeking high status or by following a set of rules or traditions. Sensitized to threat cues, the character will fight or flee (physically or psychologically) when threatened.

\section{Ingroup Security}

Orientation to feeling safe either with a constant defensive manner or through following a set of prescriptions or rules or traditions. Sensitized to threat cues, the character will fight or flee (physically or psychologically) when threatened. The character is also oriented to feeling safe through having others following a set of prescriptions or rules or traditions. High status/power is sought. When threatened, the mind can be infected with mob mentality for aggression. Aggression is justified through perceived moral tit-for-tat.
Developmental Trajectory in Care Conditions

Emotions/Drives emphasized: LOVE (LUST/CARE /ATTACHMENT), PLAY, inward SEEKING Emotions/Drives minimized: FEAR, ANGER, PANIC/SORROW

Interpersonal Engagement

Embeddededness in intersubjectively safe and close nurturing relationships that provide engaged enactive participation in social life, rooted in sensorimotor sensibilities for justice from extensive experiences of nonverbal, then verbal, reciprocity and social exchange.

\section{Ingroup Engagement}

Orientation to maintaining harmony with familiar others through empathy and concern. The reaction to threat is to tend and befriend. The character may forget self in the moment and respond with compassion, playfulness, or wisdom, transcending immediate needs.

\section{IMAGINATION}

\section{Imagination for Self}

Building on previous levels, the person is oriented to developing multiple ways to maintain group power and security (narcissism; disorganized attachment). Aberrant imagination, detached from reality.

\section{Imagination for Engagement}

Building on previous engagement capacities, the person is also oriented to helping familiar and unfamiliar others (including other societies and future generations) meet their needs to flourish in just and merciful ways.

${ }^{1}$ Documented emotional drives are in CAPS (see Panksepp, 1998).

${ }^{2}$ With maximal secure attachment, the child moves through the Security Ethics without crystallizing there. With therapy, adults can move beyond early crystallized security stances.

3 Ethics may be shallow or deep. 
and Engagement (concern for the other), for example, much like a Necker cube. Reflective capacities can override initial high emotion and guide selection among alternatives, but individuals may also select environments that match their dispositional moral orientations. Within the discussion of each ethic below, the two alternative theoretical stances towards personality are also discussed.

THREE ETHICAL ORIENTATIONS

\section{The Ethic of Security}

The Security Ethic represents the most primitive moral sense that humans display. It is rooted in the oldest parts of the brain, involving the R-complex (MacLean, 1990) or the extrapyramidal action nervous system (Panksepp, 1998). The R-complex in mammals drives territoriality, struggles for power, imitation, deception, and maintenance of routine and following precedent (MacLean, 1990). Emotion systems related to fear, rage, and seeking (exploring) reside here. For example, when safety is threatened, the parasympathetic system can trigger a fight-or-flight response (rage system); or the sympathetic system can induce freezing (fear system) to reduce pain and decrease the likelihood of bodily destruction.

The Ethic of Security is based primarily in these instincts, which revolve around safety, survival, and thriving in context, instincts shared with all animals and present from birth. Self-protective behaviors and values guard the life of the individual and the ingroup. Protecting the ingroup from outsiders is instinctual, based on the natural fear of strangers common to all animals. In safe environments, the R-complex remains calm, but when the $\mathrm{R}$-complex feels threatened in humans, it can trigger tribalism, rivalry, and mob behavior - instinctive behaviors that subvert cortical activity and that are difficult to shut down (MacLean, 1990).

When humans use the R-complex to determine moral behavior (taking an action consciously or unconsciously to secure self or ingroup), it becomes a Security Ethic. When dominant, the Security Ethic focuses on securing survival through such things as ingroup purity (Altemeyer, 2006) or ingroup maintenance of hierarchy (Nisbett \& Cohen, 1996), shown in terror management theory research (Rosenblatt, Greenberg, Solomon, Pyszczynski, \& Lyon, 1989). When not tempered by other ethics, the Security Ethic is prone to ruthlessness and attaining a security goal at any cost, decreasing sensitivity to other, even moral, goals. When people are fearful for their own safety, they are less responsive to helping 
others (Mikulincer, Shaver, Gillath, \& Nitzberg, 2005) and less able to reason carefully, because body energy (hormones, blood flow) is mobilized for safety (fight or flight). When threat is salient, individuals are more attracted to strongmen and tough policies on outsiders (Jost, Glaser, Kruglanski, \& Sulloway, 2003), as happened in the United States after 9/11/2001 (Pyszczynski, Solomon, Greenberg, Maxfield, \& Cohen, 2004) - any questioning of a strong military response or delving into alternative causes for the 9/11 attack was condemned as unpatriotic (traitorous). Such single-mindedness can lead not only to decreased sensitivity toward those who get in the way of efforts to stay safe or dominant, but also to an inability to change course, reflecting Simone Weil's view, "Evil when we are in its power is not felt as evil but as a necessity, or even a duty" (1947/1952). At the same time, what is considered evil by outsiders may be considered virtues or highly-prized principles by insiders (Skitka's "moral mandates"; Skitka \& Morgan, this volume) - such as allegiant ingroup loyalty (me vs. not-me, not the loyalty of love), obedience, and self-control of soft emotion. There is nobleness in submitting to an authority figure and "completing the mission," or accomplishing a goal considered valuable by the tradition (e.g., military service). The Security Ethic responds to the safety or dominance wishes of self and ingroup members (real or imaginary), while shutting out the needs of anyone or anything else.

Extensive early childhood distress is likely to build a foundational sense of insecurity in face of uncertainty (what is different or unfamiliar) and promote a distrustful, less empathic view of the world, outcomes documented in attachment disorders (Eisler \& Levine, 2002; Mikulincer \& Shaver, 2005). A "stressed brain" formation due to neglect or trauma (Newman, Holden \& Delville, 2005), or to a shut down of the right brain from inadequate emotional nurturance (Schore, 2003b), are postulated to lead to a personality dominated by the default systems underlying the Ethic of Security. The dominance of the default systems is most easily seen in neglected and damaged children who react to others (and to change) with mistrust, aggression, and violence (Karr-Morse \& Wiley, 1997); to behave pro-socially may require extra effortful control, which quickly uses up energy resources and becomes overly difficult (Galliot, 2008).

The Security Ethic is part of lower evolution, driven by goodness of fit and self-interest (Loye, 2002), and has been important for individual and group survival. It can be described as a more primitive moral expression emphasizing actions that appear to promote a key goal of organisms - survival. Its motives are perceived as moral imperatives. Because the systems in which the Security Ethic is based are largely hardwired, they are not easily 
damaged, making this ethic the default when the development of the other ethics goes awry.

\section{The Ethic of Engagement}

The Ethic of Engagement represents the heart of morality. The second wave of brain evolution brought about a central component of mammalian brains, the limbic system and related structures (MacLean, 1990), also known as the visceral-emotional nervous system on the hypothalamiclimbic axis (Panksepp, 1998). These formations make mammals "smarter," allowing for emotional signaling both externally (sociality) and internally (learning; Konner, 2002); they are critical to emotion, identity, memory for ongoing experience, and an individual's sense of reality and truth (Burton, 2008; MacLean, 1990). Darwin identified these as the source for human's "moral sense" (see Descent of Man, 1871/1981; or his private notebooks, Gruber, 1974)

The functionality of mammalian emotional systems is dependent on caregiving. Co-constructed during an extended childhood (Eisenberg, 1995), the infant's nervous system is dependent on caregivers as "external psychobiological” regulators (Schore, 2001, p. 202). Gradually, external regulation is transformed into internal regulation as the brain matures in response to the interaction with the environment (ibid). Mammalian brains achieve stability by means of attachment relationships throughout life with social processes such as "limbic resonance - a symphony of mutual exchange and internal adaptation whereby two mammals become attuned to each other's inner states" (Lewis, Amini, \& Lannon, 2000, p. 63). Human brains are reward-seeking structures that have evolved to obtain rewards primarily from social relationships (Nelson \& Panksepp, 1998). Without this ongoing limbic regulation, mammals, especially young ones, slip toward "physiologic chaos" (Lewis et al., p. 86; Hofer, 1987).

The Engagement Ethic is rooted in the neurobiological systems underlying mammalian parental care and social bonding. These systems depend on multiple limbic and subcortical structures and multiple types of neurotransmitters that underlie values of compassion, social harmony, and togetherness ("moral sentiments"; Moll et al, this volume. The Engagement Ethic is similar to the "extended attachment" that Moll et al. describe). Fundamental to the Engagement Ethic are early and continuous experiences of attachment. As mentioned previously, the environment of evolutionary adaptedness (Bowlby, 1988) offers mammalian brains in the first few years of life nearly constant touch, frequent breastfeeding, immediate 
responsiveness to cries, and multiple (familiar) alloparents (Hewlett \& Lamb, 2005). Proper care during development is required for normal formation of brain circuitries necessary for optimal cultural membership and moral functioning (Greenspan \& Shanker 1999; Panksepp 1998; Schore, 2003a). With adequate care, the Engagement Ethic develops fully and leads to values of compassion, tolerance, and openness to others (Eisler \& Levine, 2002). Indeed, caring moral exemplars are higher on agreeableness (Matsuba \& Walker, 2004).

Inadequate care leads to deficiencies in brain structures, hormonal regulation, and system integration resulting in brain-behavioral disorders that are related to greater hostility and aggression toward others (Kruesi, Hibbs, Zahn, Keysor, Hamburger, Bartko, \& Rapoport, 1992; Pollak \& Perry, 2005), and greater depression and anxiety (Schore, 2003a; 2003b). When a brain is wired for self-concern, it is difficult to be pro-social, perhaps due in part to the effortful control required, which quickly uses up glycogen resources (Galliot, 2008).

Warm responsive parenting in early life is related to greater conscience and empathy (Thompson, this volume; Eisenberg, Fabes \& Spinrad, 2006). Indeed, World War II rescuers of Jews typically report positive home environments (Oliner, 2002; Oliner \& Oliner, 1988). Walker and Frimer (this volume) found that, in comparison to brave exemplars, caring exemplars reported more positive childhood experiences that included secure attachment and involved mentors (indicating early life advantage, according to McAdams, this volume).

\section{The Ethic of Imagination}

The Ethic of Imagination represents the mind of morality, with its fullest expression in the human species. Although for moral exemplarity an Engagement Ethic orientation is fundamental (Colby \& Damon, 1992), the fullest capacities for moral functioning unite the Ethic of Engagement with the Ethic of Imagination.

The third brain strata to evolve involves the neocortex and related thamalic structures (MacLean, 1990), a somatic-cognitive nervous system on the thalamic-neocortical axis (Panksepp, 1998). Focused primarily on the external world, it provides the capacity for problem solving and deliberative learning. Although incapable of generating emotions themselves, "the frontal lobes have emerged as the highest center for the emotions" (Konner, 2002 , p. 135). These structures operate in coordination with the more primitive emotional systems in the older parts of the brain. That is, the mind 
"thinks with feelings" (Konner, 2002, p. 139), and when it does not, poor judgment and decision-making result (Damasio, 1999).

The Ethic of Imagination is represented primarily in these most recently evolved parts of the brain, particularly the prefrontal cortex. Connected with every distinct unit in the brain, the prefrontal cortex (PFC) integrates information from the outside world with information internal to the organism itself (Goldberg, 2002). The PFC allows an adult to impede the perhaps impetuous emotional responses of the older parts of the brain and consider alternatives based on wider perspective taking. Triune Ethics Theory suggests that the real work of moral judgment and decision-making has to do with the coordination of instincts, intuitions, reasoning and goals by the deliberative mind - the work of the Imagination Ethic.

Deliberative reasoning, one capacity of the Imagination Ethic, relies on explicit memory and develops slowly through experience and training, as Piaget and Kohlberg noted (Inhelder \& Piaget, 1958; Kohlberg, 1984), and as empirically verified by recent neuroscience (Luna, Thulborn, Munoz, Merriam, Garver, Minshew et al., 2001). Because most learning takes place implicitly and without awareness, most knowledge is tacit and unavailable to consciousness (Keil \& Wilson, 1999; Reber, 1985). A distinction has been made between the deliberative, conscious mind and the implicit mind or "adaptive unconscious" (Hassin, Uleman, \& Bargh, 2005; Wilson, 2004). Deliberation complements the intuitive and instinctive aspects of the mind, which are now presumed to dominate human functioning (Bargh \& Chartrand, 1999).The deliberative tools of the Imagination Ethic respond to, and coordinate, the intuitions and instincts of the Engagement Ethic and the Security Ethic, which operate according to conditioned and implicitly extracted moral "principles."

The Imagination Ethic uses at least two powerful tools. One is "free won't," the ability to countermand instincts and intuitions (Cotterill, 1999), an ability that allows humans to choose which stimuli are allowed to trigger emotional arousal or action sequences (Panksepp, 1998). The Imagination Ethic is rooted in typically left-brain activities of linear thinking, past and future orientation, and other aspects critical to an individual sense of self (Taylor, 2008). The conscious, deliberative mind allows the individual to consider choices and select activities and environments that foster particular intuitions in the subconscious part of the brain (Hogarth, 2001). When this is done for value purposes, it reflects the Imagination Ethic in action.

A second tool of the Imagination Ethic is the ability to frame behavior, to explain the past and imagine the future (Gazzaniga, 1985; Taylor, 2008), which contribute to building a life narrative and motivating the self (a focus 
of several chapters in this volume). Cultural narratives are often adopted and translated into personal narratives, propelling behavior. Narratives may promote peace or conflict, pro-social or antisocial views and enlist the resources of an individual to take up particular goals and actions. For example, Eidelson and Eidelson (2003) extracted five beliefs that promote group conflict, operating at the individual or group level: vulnerability, distrust, helplessness, injustice, and superiority - all of which provoke the Security Ethic. In contrast, redemptive narratives (McAdams, this volume) and gratitude framing (Emmons, this volume) are instances of ethical framing that promote the Engagement Ethic. Religious communities constantly discuss, model, and imitate moral exemplarity, bringing about a greater likelihood for chronic accessibility of particular constructs in their members, especially if alternatives are not presented. But the moral constructs emphasized by religious communities vary. For example, the Amish chronically activate compassion (Engagement) whereas Israeli and Palestinian extremists chronically activate a sense of injustice and threat (Security).

Like the brain areas related to the Engagement Ethic, brain areas related to the Ethic of Imagination require a nurturing environment to develop properly. Schore (2003a; 2003b) marshals a great deal of evidence to show how the development of the orbitofrontal cortex (OFC), critical for lifelong emotion regulation, is dependent on early co-regulation by the caregiver in the first months of life. Poor care may permanently damage the OFC, predisposing the individual to psychiatric disorders, such as anxiety or depression, and suboptimal functioning throughout life. Taking decades to fully develop (Giedd, Blumenthal, \& Jeffries 1999; Luna, Thulborn, Munoz, Merriam, Garver, Minshew et al., 2001), the prefrontal cortex and its specialized units can be damaged from environmental neglect or abuse, both early (Anderson, Bechara, Damasio, Tranel, \& Damasio, 1999; Kodituwakku, Kalberg, \& May, 2001) and late in development (Newman, Holden, \& Delville, 2005). The prefrontal cortex is susceptible to damage in adolescence and early adulthood through physiologically addictive activities, such as binge drinking (Bechara, 2005) and violent video game play (Mathews, Kronenberger, Wang, Lurito, Lowe, \& Dunn, 2005).

The work of the Imagination Ethic, which must be cultivated through deliberative study, offers the means for greater awareness outside the self. The Imagination Ethic enables a sense of community that extends beyond immediate relations, valuing universality and outsiders, and conceptualizing alternative sophisticated resolutions of moral problems. Although more detached from the basic emotional drives of the other ethics, the Imagination Ethic can be implicitly motivated by one of the other ethics. The 
open-heartedness of the Engagement Ethic fuels an imagination of helpfulness and altruism, while the closed rigidity of the Security Ethic fosters an imagination towards defense and perhaps offense. When the Engagement Ethic and the Imagination Ethic have been poorly nurtured by the caregiver and community, or there is significant trauma, the Security Ethic becomes the default system. To reiterate, humans are at their most moral, following Darwin's moral evolution, when the Ethic of Engagement (compassionate regard) is linked with the Ethic of Imagination (extended engagement).

\section{IMPLICATIONS FOR MORAL PERSONALITY THEORY}

Triune Ethics Theory emphasizes the importance of attending to the fundamental nature of organisms, mammals, and humans when considering moral functioning. Two aspects addressed here are that organisms are by nature goal driven, whether it be in seeking sustenance or stimulation, and when the goals of the moment are considered good by the organism. Mammals are more keenly guided by emotions, and humans have the additional capacity for reasoned reflection. Because of the way human brains have evolved encompassing diverse systems, a person can have multiple, sometimes competing, goals.

\section{Morality of the Moment}

The view presented here is that all humans believe themselves to be moral agents in the moment, as they aim for what appears good in the moment even the criminal attempts to "right wrongs" or restore justice to his or her world, even if it is through the processes of moral disengagement (Bandura, 1999). It is against commonsense and nature for creatures to aim for what they think is bad in the moment. "Good" is what the organism believes will meet the current drive or aim. Goals are not always conscious motives. Humans are made up of multiple competing biological systems with their own goals, or good ends (e.g., goals for energy, rest, being safe, affiliation, transcendence, etc.). At any given moment, it is likely that a person has more than one goal of interest, whose priority may shift with changing appraisals of the situation. Bandura (1999) has shown how one's goals and interests can lead to moral disengagement, a process that involves typically, in TET terminology, shutting down the Engagement Ethic and focusing on Security Ethic goals, all for what seems "right" in the moment.

The individual's internal aims and drives interact with the situation in various ways. Organisms respond to environmental press (social and 
non-social) by shifting goals or subgoals. Affective expectancies (e.g., fear, love) influence perceptual sensitivities (Wilson, Lisle, Kraft \& Wetzel, 1989). Perceived affordances (social, physical, and action possibilities) are influenced by prior experience and expertise (Neisser, 1976), as well by current goals (Gibson, 1979). Based on experiences and goals, one is attracted to rhetoric that supports those goals, regardless of accuracy (Burton, 2008). The situation also affects behavioral outcome expectancies and preferred subgoals (Mischel's "subjectively valuable outcomes," 1973, p. 270). For example, when a person is threatened, he is more attuned to threat cues. The affordances noticed centralize around self-advantageous and ingroupadvantageous actions; "shoot to kill" sounds like a more reasonable command, and goals of control may be more attractive - all of which contribute to using a Security Ethic. Situations provide a "press" toward one ethic or another - the "power of the situation," as reflected in behavior of most inmates in Nazi concentration camps (Levi, 1958) or the guards at Abu Ghraib Prison (Zimbardo, 2007). Laboratory studies show that Security goals or Engagement goals can be primed, influencing both subsequent helping behavior and attitudes toward, and treatment of, outgroup members (terror management studies; Hart, Shaver, Goldenberg, 2005; Mikulincer \& Shaver, 2001).

Goal focus is a shifting, situational aspect of moral functioning. But as seen in moral exemplar research, some people have chronic moral goals as well.

\section{Dispositional Multiplicity of Moral Personality}

Several theorists are questioning the psychological feasibility of a singular notion of identity (Cervone \& Tripathi, this volume; Markus \& Nurius, 1986; Wong, this volume). TET agrees that the individual potentially has multiple selves and multiple moral identities. The three ethical motivations may conflict: for example, a person may struggle against feeling threatened while trying to maintain a sense of compassion. The individual may feel a sense of "moral ambivalence" because of underlying "moral value pluralism" (Wong, 2006). For instance, as a person is victimized, does one stand by like everyone else in order to avoid looking foolish, or does one put selfconcern aside and operate from compassion and intervene? Small and large choices like these are daily affairs; the different ethics offer strikingly different courses of action. An individual's moral identity can shift with how the individual apprehends the demands of the context and personal self-efficacy to meet them. For example, a person may flip between ethical stances, as 
did the Nazi, Joseph Goebbels, who showed moments of compassion toward Jews, which he later offset with greater cruelty (Arpaly, 2003).

Because each ethic is available to some degree in each person (although damaged or deficient brains may offer fewer resources for engagement or imagination), the self is not necessarily consistent in its moral orientation. There are several examples of shifting moral identities in this volume. For example, Aquino points out how a person's competing identities or working self-concepts (Markus \& Kunda, 1986) are evoked by situational affordances. Aquino and colleagues find that different moral identities are activated through financial rewards, role models, and situational norms. Monin and Jordan (this volume) reveal how individuals keep moral balance sheets, which allow for self-sanctioned indiscretion after paying one's moral dues with effortful moral behavior. Aquino and Freeman points out the flexibility in defining morality, which leads to an easy moral disengagement so that a person can take a desired immoral action (Bandura et al., 1996).

More mature personalities may be more consistent (i.e., Loevinger, 1972). Some individuals may not be overpowered by a situation (Frankl, 1963), displaying an idiosyncratic person-by-context personality signature. Chronic personality orientations probably shift less between ethics, or have primary controls to keep from shifting into an unfamiliar direction. For example, although aggression cues promote hostile thoughts and actions in most people, individuals high in agreeableness may activate pro-social responses instead (Meier, Robinson, \& Wilkowski, 2006). Expertise in selfforgetting and compassionate response may prevent Security Ethic activation (e.g., among Buddhist monks).

Dispositional moral orientations rely on sensitive periods of development. In the first few years of life, the ground is laid for engagement and imagination. But there appear to be other sensitive periods, such as early adolescence (for engagement) and emerging adulthood (especially for imagination; Narvaez, Getz, Rest, \& Thoma, 1999). Situational sensitivity has been explored by social psychologists. However, the person-by-context interaction needs further research.

\section{CONCLUSION}

The primary contribution of Triune Ethics Theory is to point out the importance of initial conditions for human development and how these may influence brain structures and circuitry, affecting moral functioning in sometimes subtle ways. In order to act with situation-appropriate compassion 
and imagination - the heart and mind of morality - individuals must have capabilities for self-regulation (e.g., self-soothing) and connecting to others (e.g., social limbic resonance), based on well-developed limbic and cortical structures established in early life, or in subsequent sensitive periods of development (which could include psychotherapy).

Ethical capacities rely on longstanding childrearing and social practices that are often missing in modern societies. Even if neglect is less than profound, its effects on the formation of systems that promote the Engagement Ethic can be long lasting. A child who spends a great deal of time alone in his or her room develops a different social orientation and embodied understanding of the social world than a child who co-sleeps with parents and siblings and is never isolated. As Lewis et al. (2000) point out:

A child enveloped in a particular style of relatedness learns its special intricacies and particular rhythms, as he distills a string of instances into the simpler tenets they exemplify. As he does so, he arrives at an intuitive knowledge of love that forever evades consciousness (p. 116, emphasis added).

TET also leads one to conclude that the approaches typically taken toward moral education - advocacy by adults for particular behaviors, or reasoned reflection about one's ideals, and shaping one's behavior accordingly from the top down - are, upside down. Instead, moral selves emerge from lived experience that is largely stored in non-conscious neurological and endocrine systems (Damasio, 1999). Immersion in good relationships and communities fosters the intuitions upon which rationality is built (Greenspan \& Shanker, 2004). Then, after immersion in a complex social world, explicit discussion and guidance about good behavior makes sense as skills are honed towards expertise (Narvaez, 2006).

In the EEA of the Pleistocene era, humans lived in small, tight-knit groups. There, a good life and a life that survived/reproduced/thrived were the same thing. Contrarily, in the "civilized" world, individuals are able to survive physically even though they are socially or morally deformed and live "bad" lives (lives of disorganized emotion, cognition and behavior that cause harm to themselves and others). Starting life without the rich soil of mutually responsive caregivers leaves a child with shallow roots in sociomoral functioning, tenuous self-regulation, and a self-oriented neurobiology. Children with these characteristics are less compliant with adults and rules (Kochanksa, Aksan, Prisco, \& Adams, 2008), more dangerous to themselves and their communities Karr-Morse \& Wiley, 1997), and must spend a greater amount of more limited energy to self-regulate for 
life success. It is time to pay attention to the types of biologically supportive environments that promote optimal moral formation and alleviate the maternal and familial stressors that promote stunted moral growth.

\section{REFERENCES}

Altemeyer, R. (2006). The authoritarians. Lulu.com: Robert Altemeyer.

Anderson, S. W., Bechara, A., Damasio, H., Tranel, D., \& Damasio, A.R. (1999). Impairment of social and moral behavior related to early damage in human prefrontal cortex, Nature Neuroscience, 2, 1032-1037.

Aquino, K., \& Freeman, D. (this volume). Moral identity in business situations: A social-cognitive framework for understanding moral functioning. In D. Narvaez \& D. K. Lapsley (Eds.), Personality, identity, and character explorations in moral psychology (pp. $\mathrm{xx}-\mathrm{xx}$ ). New York: Cambridge University Press.

Arpaly, N. (2003). Unprincipled virtue: An inquiry into moral agency. New York: Oxford University Press.

Audero, E., Coppi, E., Mlinar, B., Rossetti, T., Caprioli, A., Al Banchaabouchi, M., Corradetti, R., \& Gross, C. (2008). Sporadic autonomic dysregulation and death associated with excessive serotonin autoinhibition. Science, 321, 130-133.

Bandura, A. (1999). Moral disengagement in the perpetration of inhumanities. Personality and Social Psychology Review, 3(3), 269-275.

Bargh, J.A. (1989). Conditional automaticity: Varieties of automatic influence in social perception and cognition. In J.S. Uleman \& J.A. Bargh (Eds.), Unintended thought (pp.3-51). New York: Guilford.

Bauerlein, M. (2008). The dumbest generation: How the digital age stupefies young Americans and jeopardizes our future. New York: Tarcher/Penguin.

Bechara, A. (2005). Decision making, impulse control and loss of willpower to resist drugs: a neurocognitive perspective. Nature Neuroscience 8, 1458-1463.

Bowlby, J. (1973). Attachment and loss. New York: Basic Books.

(1988) A secure base: Parent-child attachment and healthy human development. New York: Basic Books.

Bugental, D.B., \& Goodnow, J.J. (1998). Socialization processes. In W. Damon (Series Ed.) \&. N. Eisenberg (Vol. Ed.), Handbook of child psychology, 5 th. ed. (pp.389-462). New York: John Wiley \& Sons.

Burton, R. A. (2008). On being certain: Believing you are right even when you are not. New York: St. Martin's Press.

Caspi, A., Sugden, K., Moffitt, T.E., Taylor, A., Craig, I. W., Harrington, W., McClay, J., Mill, J., Martin, J., Braithwaite, A., \& Poulton, R. (2003). Influence of life stress on depression: Moderation by a polymorphism in the 5 -HTT gene. Science, 301, 386-89.

Centers for Disease Control. (2004). National Immunization Survey. Atlanta, GA: $\mathrm{CDC}$

Cervone, D. (1999). Bottom-up explanation in personality psychology: The case of cross-situational coherence. In D. Cervone \& Y. Shoda (Eds.), The coherence of personality: Social-cognitive bases of personality consistency, variability, and organization (pp.303-341). New York: Guilford Press. 
Cervone, D., \& Tripathi, R. (this volume). The moral functioning of the person as a whole: On moral psychology and personality science. In D. Narvaez \& D. K. Lapsley (Eds.), Personality, identity, and character explorations in moral psychology (pp. $\mathrm{xx}-\mathrm{xx}$ ). New York: Cambridge University Press.

Champagne, F. A., \& Meaney, M. J. (2006). Stress during gestation alters maternal care and the development of offspring in a rodent model. Biological Psychology, $59,1227-1235$.

Cotterill, R. (1998). Enchanted looms. Cambridge, England: Cambridge University Press.

Damasio, A. (1994). Descartes' error. New York: Avon Books.

(1999). The feeling of what happens. London: Heineman.

Darley, J., \& Batson, C. D. (1973). From Jerusalem to Jericho: A study of situational and dispositional variables in helping behavior. Journal of Personality and Social Psychology, 27, 100-108.

Dentan, R.K. (1968). The Semai: A nonviolent people of Malaya. New York, NY: Harcourt Brace College Publishers.

Demos, E. V. (1995). Exploring affect: The selected writings of Silvan S. Tomkins. Cambridge, England: Cambridge University Press.

Eidelson, R. J., \& Eidelson, J.I. (2003). Dangerous ideas: Five beliefs that propel groups toward conflict. American Psychologist, 58, 182-192

Eisenberg L. (1995). The social construction of the human brain. American Journal of Psychiatry, 152, 1563-1575.

Eisenberg, N., Fabes, R.A., \& Spinrad, T.L. (2006). Prosocial development. In W. Damon (Series Ed.) \&. N. Eisenberg (Vol. Ed.), Handbook of child psychology, 6th. ed. (pp. 646-718). New York: John Wiley \& Sons.

Eisler, R.. \& Levine, D. S. (2002). Nurture, nature, and caring: We are not prisoners of our genes. Brain and Mind, 3, 9-52.

Frankl, Viktor E. (1963). Man's search for meaning. New York: Simon and Schuster.

Franklin, K. M., Janoff-Bulman, R., \& Roberts, J.E. (1990). Long-term impact of parental divorce on optimism and trust: changes in general assumptions or narrow beliefs. Journal of Personality and Social Psychology, 59, 743-755.

Galliot, M.T. (2008). Unlocking the energy dynamics of executive functioning: Linking executive functioning to brain glycogen. Perspectives on Psychological Science, 3(4), 245-263.

Gazzaniga, M.S. (1995). Consciousness and the cerebral hemispheres. In M.S. Gazzaniga (Ed.), The cognitive neurosciences (pp.1391-1399). Cambridge, MA: MIT Press.

Gibson, J. (1979). The ecological approach to perception. Hillsdale, NJ: Erlbaum.

Giedd, J. N., Blumenthal, J, Jeffries, N.O. et al. (1999). Brain development during childhood and adolescence: A longitudinal MRI study. Nature Neuroscience, 2(10), 861-3.

Gluckman, P., \& Hanson, M. (2004). The fetal matrix: Evolution, development and disease. New York: Cambridge University Press.

Goldberg, E. (2002). The Executive brain: Frontal lobes and the civilized brain. New York: Oxford University Press.

Greenspan, S.I., \& Shanker, S. I. (2004). The first idea. Cambridge, MA: Da Capo Press. 
Gruber, H. (1974). Darwin on man: A psychological study of scientific creativity. Chicago: University of Chicago Press.

Hart, J., Shaver, P.R., \& Goldenberg, J.L. (2005). Attachment, self-esteem, worldviews, and terror management: Evidence for a tripartite security system. Journal of Personality and Social Psychology, 88 (6), 999-1013.

Hassin, R. R., Uleman, J.S., \& Bargh, J. A. (Eds.) (2005). The new unconscious. New York: Oxford University Press.

Henry, J.P., \& Wang, S. (1998). Effects of early stress on adult affiliative behavior, Psychoneuroendocrinology 23(8), 863-875.

Hewlett, B.S., \& Lamb, M.E. (2005). Hunter-gatherer childhoods: evolutionary, developmental and cultural perspectives. New Brunswick, NJ: Aldine.

Hofer, M. A. (1994). Hidden regulators in attachment, separation, and loss. In N. A. Fox (Ed.), Emotion regulation: Behavioral and biological considerations. Monographs of the Society for Research in Child Development, 59, 192-207.

(1987). Early social relationships as regulators of infant physiology and behavior. Child Development, 58(3), 633-647.

Hogarth, R.M. (2001). Educating intuition. Chicago, IL: University of Chicago Press.

Hrdy, S. B. (1999). Mother Nature: Maternal instincts and how they shape the human species. New York: Ballantine.

Inhelder, B., \& Piaget, J. (1958). The growth of logical thinking from childhood to adolescence. New York: Basic Books.

Jacoby, S. (2008). The American age of unreason. New York: Pantheon.

Jackson, M. (2008). Distracted: The erosion of attention and the coming dark age. Amherst, NY: Prometheus.

Jost, J.T., Glaser, J., Kruglanski, A. W., \& Sulloway, F. J. (2003). Political conservatism as motivated social cognition. Psychological Bulletin, 129(3), 339-375.

Kalin, N.H. (1999). Primate models to understand human aggression. Journal of Clinical Psychiatry, 60 (15), 29-32.

Karr-Morse, R., \& Wiley, M.S. (1997). Ghosts from the nursery: Tracing the roots of violence. New York: Atlantic Monthly Press.

Keil, F. C., \& Wilson, R. A. (1999). Explanation and cognition. Cambridge, MA: MIT Press.

Kochanska, G. (2002b). Mutually responsive orientation between mothers and their young children: A context for the early development of conscience. Current Directions in Psychological Science, 11, 191-195.

Kodituwakku, P. W., Kalberg, W., \& May, P. A. (2001). The effects of prenatal alcohol exposure on executive functioning. Alcohol Research and Health, 25(3), 192-198.

Kohlberg, L. (1984). Essays on moral development, Volume 2: The psychology of moral development. San Francisco: Harper \& Row.

Konner, M. (2002). The tangled wing. New York: Owl Books.

Kruesi, M. J., Hibbs, E. D., Zahn, T. P., Keysor, C. S., Hamburger, S. D., Bartko, J. J., \& Rapoport, J. L. (1992). A 2-year prospective follow-up study of children and adolescents with disruptive behavior disorders. Prediction by cerebrospinal fluid 5-hydroxyindoleacetic acid, homovanillic acid, and autonomic measures? Archives of General Psychiatry, 49(6):429-435. 
Lapsley, D. \& Narvaez, D. (2004). A social-cognitive view of moral character. In D. Lapsley \& D. Narvaez (Eds.), Moral development: Self and identity (pp.189-212). Mahwah, NJ: Erlbaum.

Lesch, K., Bengel, D., Heils, A., Sabol, S.Z., Greenberg, B.D., Petri, S., Clemens, R., Müller, J. B., Hamer, D. H., \& Murphy, D. L. (1996). Association of anxietyrelated traits with a polymorphism in the serotonin transporter gene regulatory region. Science, 274, 1527-31.

Levi, P.(1959) Survival in Auschwitz. New York: Touchstone.

Lewis, T., Amini, F., \& Lannon, R. (2000). A general theory of love. New York: Vintage.

Loevinger, J. (1976) Ego development. San Francisco: Jossey-Bass.

Loye, D. (2002). The moral brain. Brain and Mind, 3, 133-150.

(2000). Darwin's lost theory of love. New York: Writer's Press.

Luna, B., Thulborn, K. R., Munoz, D. P., Merriam, E. P., Garver, K. E., Minshew, N. J. et al. (2001). Maturation of widely distributed brain function subserves cognitive development. NeuroImage, 13(5), 786-793.

MacLean, P. D. (1973). A triune concept of the brain and behavior. Toronto: University of Toronto Press.

(1990). The triune brain in evolution: Role in paleocerebral functions. New York: Plenum.

Markus, H., \& Kunda, Z. (1986). Stability and malleability of the self-concept. Journal of Personality and Social Psychology, 51(4), 858-866.

Markus, H., \& Nurius, P. (1986). Possible selves. American Psychologist, 41, 954-969.

Mathews, V.P., Kronenberger, W.G., Wang, Y., Lurito, J.T., Lowe, M.J., \& Dunn, D.W. (2005). Media violence exposure and frontal lobe activation measured by functional magnetic resonance imaging in aggressive and nonaggressive adolescents. Journal of Computer Assisted Tomography, 29 (3), 287-292.

Matsuba, M.K., \& Walker, L. J. (2004). Extraordinary moral commitment: Young adults involved in social organizations. Journal of Personality, 72 (2), 413-436.

McAdams, D. (this volume). The moral personality. In D. Narvaez \& D. K. Lapsley (Eds.), Personality, identity, and character explorations in moral psychology (pp. $\mathrm{xx}-\mathrm{xx}$ ). New York: Cambridge University Press.

Meier, B. P., Robinson, M.D., \& Wilkowski, B. M. (2006). Turning the other cheek: Agreeableness and the regulation of aggression-related primes. Psychological Science, 17(5), 136-142.

Mikulincer, M., \& Shaver, P. R. (2005). Attachment security, compassion, and altruism. Current Directions in Psychological Science, 14, 34-38.

Mikulincer, M., Shaver, P.R., Gillath, O., \& Nitzberg, R. A. (2005). Attachment, caregiving, and altruism: boosting attachment security increases compassion and helping. Journal of Personality and Social Psychology, 89 (5), 817-839.

Mischel, W. (1973). Towards a cognitive social learning theory reconceptualization of personality. Psychological Review, 80, 252-283.

Moll, J., de Oliveira-Souza, R., Eslinger, P.J., Bramati, I.E., Mourao-Miranda, J., Andreiulo, P.A. et al. (2002). The neural correlates of moral sensitivity: A functional magnetic resonance imaging investigation of basic and moral emotions. Journal of Neuroscience, 22, 2730-2736. 
Moll, J., Zahn, R., de Olivera-Souza, R., Krueger, F., \& Grafman, J. (2005). The neural basis of human moral cognition. Nature Reviews: Neuroscience, 6, 799-809.

Moll, J., de Oliveira-Souza, R., \& Zahn, R. (this volume). Neuroscience and morality: Moral judgments, sentiments and values. In D. Narvaez \& D. K. Lapsley (Eds.), Personality, identity, and character explorations in moral psychology (pp. $\mathrm{xx}-\mathrm{xx}$ ). New York: Cambridge University Press.

Monin. B., \& Jordan, A. (this volume). The dynamic moral self: A social psychological perspective. In D. Narvaez \& D. K. Lapsley (Eds.), Personality, identity, and character explorations in moral psychology (pp. $\mathrm{xx}-\mathrm{xx}$ ). New York: Cambridge University Press.

Narvaez, D. (2008). Triune ethics: The neurobiological roots of our multiple moralities. New Ideas in Psychology, 26, 95-119.

Narvaez, D., \& Vaydich, J. (2008). Moral development and behaviour under the spotlight of the neurobiological sciences. Journal of Moral Education, 37(3), 289-313.

Neisser, U. (1976). Cognition and reality. New York: W.H. Freeman and Company.

Nelson, E. E., \& Panksepp, J. (1998). Brain substrates of infant-mother attachment: contributions of opioids, oxytocin, and norepinephrine. Neuroscience and Biobehavioral Reviews, 22, 437-452.

Newman, M.L., Holden, G.W., \& Delville, Y. (2005). Isolation and the stress of being bullied. Journal of Adolescence, 28, 343-357.

Nisbett, R., \& Cohen, D. (1996). Culture of honor. New York: Westview Press.

Oliner, S.P. (2002). Extraordinary acts of ordinary people: Faces of heroism and altruism. In S. G. Post, L. G. Underwood, J.P. Schloss, \& W. B. Hurlbut (Eds.), Altruistic love: science, philosophy, and religion in dialogue (pp.123-139). New York: Oxford University Press.

Oliner, S. P., \& Oliner, P. M. (1988). The altruistic personality: Rescuers of Jews in Nazi Europe. New York: Free Press.

Panksepp, J. (1998). Affective neuroscience: The foundations of human and animal emotions. New York: Oxford University Press.

Paterson, D., Trachtenberg, F.L., Thompson, E. G., Belliveau, R. A., Beggs, A.H., Darnall, R., Chadwick, A. E., Krous, H. F., Kinney, H. C. (2006). Multiple serotonergic brainstem abnormalities in sudden infant death syndrome. Journal of the American Medical Association, 296, 2124-2132.

Pollak, S.D., \& Perry, B. (2005). Early neglect can hinder child's relationships. Proceedings of the National Academy of Sciences, Nov. 21-25.

Prescott, J. W. (1996). The origins of human love and violence. Pre- and Perinatal Psychology Journal, 10 (3), 143-188.

Putnam, R. D. (2001). Bowlingalone: The collapse and revival of American community. New York: Simon \& Schuster.

Pyszczynski, T., Solomon, S., Greenberg, J., Maxfield, M., \& Cohen, F. (2004). Fatal attraction. The effects of mortality salience on evaluations of charismatic, task-oriented, and relationship oriented leadership. Personality and Social Psychology Bulletin, 32 (4), 525-537

Reber, A.S. (1993). Implicit learning and tacit knowledge: An essay on the cognitive unconscious. New York: Oxford University Press. 
Rosenblatt, A., Greenberg J., Solomon S., Pyszczynski, T., \& Lyon D. (1989). Evidence for terror management theory: I. The effects of mortality salience on reactions to those who violate or uphold cultural values. Journal of Personality and Social Psychology, 57(4), 681-90.

Shenkman, R. (2008). Just how stupid are we: Facing the truth about the American voter. New York: Basic Books.

Schore, A.N. (2001). The effects of early relational trauma on right brain development, affect regulation, and infant mental health. Infant Mental Health Journal, 22, 201-269.

(2003a). Affect regulation and the repair of the self. New York: Norton.

(2003b). Affect dysregulation and disorders of the self. New York: Norton.

Skitka, L.J., \& Morgan, G.S. (this volume). The double-edged sword of a moral state of mind. In D. Narvaez \& D. K. Lapsley (Eds.), Personality, identity, and character explorations in moral psychology (pp. $\mathrm{xx}-\mathrm{xx})$. New York: Cambridge University Press.

Taylor, J. B. (2008). My Stroke of insight: A brain scientist's personal journey. New York: Viking Press.

Thomas, E. M. (1959). The armless people. New York: Vintage.

Thompson, R. (this volume). Early foundations: Conscience and the development of moral character. In D. Narvaez \& D. K. Lapsley (Eds.), Personality, identity, and character explorations in moral psychology (pp. $\mathrm{xx}-\mathrm{xx}$ ). New York: Cambridge University Press.

Tomkins, S. (1965). Affect and the psychology of knowledge. In S.S. Tomkins \& C. E. Izard (Eds.), Affect, cognition, and personality. New York: Springer.

Twenge, J. M. (2000). The age of anxiety? Birth cohort change in anxiety and neuroticism, 1952-1993. Journal of Personality and Social Psychology, 79(6) 1007-1021.

U.S. Department of Health and Human Services, Substance Abuse and Mental Health Services Administration. (1999). Mental health: A Report of the surgeon general. Rockville, MD: Center for Mental Health Services, National Institutes of Health, National Institute of Mental Health.

Walker, L. J., \& Frimer, J. (this volume). Moral personality exemplified. In D. Narvaez \& D. K. Lapsley (Eds.), Personality, identity, and character explorations in moral psychology (pp. xx-xx). New York: Cambridge University Press.

Weaver, I. C., Szyf, M., \& Meaney, M. J. (2002). From maternal care to gene expression: DNA methylation and the maternal programming of stress responses. Endocrine Research, 28, 699.

Weil, S. (1947/1952). Gravity and grace. New York: Routledge Kegan Paul.

Wilson, T.D. (2004). Strangers to ourselves. New York: Belknap.

Wong, D. B. (2006). Natural moralities. New York: Oxford University Press.

Wong, D. (this volume). Pluralism and moral identity. In D. Narvaez \& D. K. Lapsley (Eds.), Personality, identity, and character explorations in moral psychology (pp. $\mathrm{xx}-\mathrm{xx})$. New York: Cambridge University Press.

Zimbardo, P. (2007). The Lucifer effect: Understanding how good people turn bad. New York: Random House.Darcia Narvaez 